\title{
Blue colored pigment phycocyanin extraction from Spirulina platensis
}

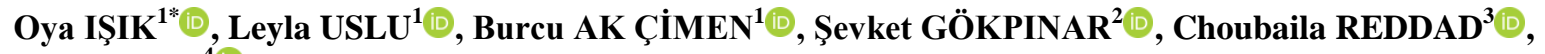 Selin SAYIN ${ }^{4}$}

${ }^{1}$ Çukurova University, Fisheries Faculty, Basic Science Department, Adana, Turkey

${ }^{2}$ Ege University, Fisheries Faculty, Aquaculture Department, İzmir, Turkey

${ }^{3}$ Cukurova University, Department of Biotechnology, Adana, Turkey

${ }^{4}$ İskenderun Technical University, Faculty of Marine Sciences and Technology İskenderun, Turkey

*Corresponding Author: oyaisik@cu.edu.tr

Received 08 May 2020; Accepted 23 June 2020; Release date 01 December 2020.

How to Cite: Işık, O., Uslu, L., Ak Çimen, B., Gökpınar, Ş., Reddad, C., \& Sayın, S. (2020). Blue colored pigment phycocyanin extraction from Spirulina platensis. Acta Aquatica Turcica, 16(4), $506-510$ https://doi.org/10.22392/actaquatr.732774

\begin{abstract}
Phycocyanin is a blue pigment and water-soluble biliprotein from the Spirulina platensis. In this study, the water was used as a solvent for the extraction of phycocyanin. Wet biomass of Spirulina, wet biomass held for 48 hours at room temperature, frozen Spirulina for 48 hours, and frozen biomass for fifteen days, and dried Spirulina was used to determine phycocyanin concentration $(\mathrm{PC})\left(\mathrm{mg} \mathrm{mL}^{-1}\right)$. At the same time, extract purity of phycocyanin $\left(\mathrm{OD}_{615} / \mathrm{OD}_{280}\right)$ and yield (mg g ${ }^{1}$ ) were determined. Phycocyanin yield of 17,6497, 17,1370, and 17,0833 $\mathrm{mg} \mathrm{g}^{-1}$ were obtained from frozen Spirulina for fifteen days, wet biomass of Spirulina held for 48 hours, and wet biomass of Spirulina, respectively. The purity ratios $\left(\mathrm{OD}_{615} / \mathrm{OD}_{280}\right)$ of $4.60,0.81,0.85,0.98$, and 6.55 were determined for frozen for 15 days, frozen Spirulina for 48 hours, wet biomass of Spirulina (waited for 48 hours), dried Spirulina and wet Spirulina, respectively.
\end{abstract}

Keywords: Phycocyanin, extraction, solvent, C-PC yield

Spirulina platensis'ten mavi pigment fikosiyanin ekstraksiyonu

Özet

Fikosiyanin, Spirulina platensis'ten elde edilen ve suda çözünebilen mavi pigmenttir. Bu çalışmada fikosiyanin ekstraksiyonu için çözücü olarak su kullanılmıştır. Fikosiyanin konsantrasyonunu (PC) $\left(\mathrm{mg} \mathrm{mL}^{-1}\right)$ belirlemek için yaş Spirulina biyoması, oda sıcaklığında 48 saat beklemiş yaş biyomas, 48 saat dondurulmuş Spirulina, 15 gün dondurulmuş Spirulina ve kuru Spirulina kullanılmıştır. Aynı zamanda Fikosiyanin saflı̆̆ $\left(\mathrm{OD}_{615} / \mathrm{OD}_{280}\right)$ ve ürün miktarı $\left(\mathrm{mg} \mathrm{g}^{-1}\right)$ saptanmıştır. Onbeşgün dondurulmuş Spirulina,48 saat oda sıcaklığında beklemiş yaş biyomas ve yaş Spirulina biyomasından, sırasıyla $17,6497,17,1370$ ve $17,0833 \mathrm{mg} \mathrm{g}^{-1}$ fikosiyanin elde edilmiştir. Üründeki saflık oranları $\left(\mathrm{OD}_{615} / \mathrm{OD}_{280}\right), 4.60,0.81,0.85,0.98$ ve 6.55, sırasıyla onbeşgün dondurulmuş Spirulina, 48 saat dondurulmuş Spirulina, 48 saat bekletilmiş yaş Spirulina biyoması, kurutulmuş Spirulina ve yaş biyomastan elde edilmiştir.

Anahtar kelimeler: Fikosiyanin, ekstraksiyon, çözücü, C-PC ürün

\section{INTRODUCTION}

Phycocyanin is an accessory photosynthetic blue colored pigment of Spirulina sp. Cyanobacteria Spirulina platensis is an excellent source of phycocyanin. C-phycocyanin(C-PC) is the major phycobiliprotein and may constitute up to $20 \%$ of the dry weight of Spirulina (Jaouen et al., 1999; Vonshak, 1997). C-PC has been widely investigated concerning its characteristics and commercial potential. The application of C-PC has been examined in a wide range of fields. Phycocyanin is a natural blue colorant, has uses as a food colorant for chewing gum, ice sherbets, soft drinks, candies, and cosmetics including lipstick and eyeliners. Phycocyanin is also used as biochemical tracers in immunoassays due to its fluorescent properties (Herrera et al., 1989; Silveira et al., 2007). Furthermore, phycocyanin has been proven to have therapeutic properties including antioxidant, antiinflammatory, and anti-cancer activities (Romay et al., 2003; Eriksen, 2008).

Several factors can influence the phycocyanin extraction. The most important are, cellular disruption method, type of solvent, biomass-solvent ratio, and extraction time (Abalde et al., 1998; 
Reis et al., 1998). Many studies on efficient extraction and purification of C-PC have been carried out. Phycocyanin extraction was evaluated in terms of phycocyanin concentration using different solvents, including distilled water, sodium phosphate, and sodium acetate buffers, $\mathrm{NaCl}, \mathrm{CaCl}_{2}$ (Abalde et al., 1998; Bermejo et al., 2003, Ilter et al., 2018).

In the present study, the water as a solvent for phycocyanin extraction from S. platensis was investigated. In the study we carried out, C-PC contents were determined from the wet biomass of Spirulina, wet biomass of Spirulina held for 48 hours at room temperature, frozen Spirulina for 48 hours, and frozen biomass for fifteen days and dried Spirulina. Phycocyanin concentration (PC) (mg $\left.\mathrm{mL}^{-1}\right)$, extract purity of phycocyanin $\left(\mathrm{OD}_{615} / \mathrm{OD}_{280}\right)$, and yield $\left(\mathrm{mg} \mathrm{g}^{-1}\right)$ were determined in the samples.

\section{MATERIALS and METHODS}

In the study, the blue-green alga Spirulina platensis was cultured at the fiber-glass ponds with a size of $1 \times 5 \times 0.2$ meter and 1 ton capacity in the greenhouse of the Algal Biotechnology Pilot Plant, Fisheries Faculty, Cukurova University, Turkey were used. There is a pedal system that provides mixing with a speed of $20 \mathrm{~cm} \mathrm{sn}^{-1}$ in the ponds. The cultures were harvested by filtering. The wet biomass of Spirulina, the wet biomass of Spirulina held for 48 hours at room temperature, frozen Spirulina at $-22{ }^{\circ} \mathrm{C}$ for 48 hours and frozen at $-22{ }^{\circ} \mathrm{C}$ for fifteen days and Spirulina dried at $55{ }^{\circ} \mathrm{C}$ and stored at room temperature were used to extract and purify.

Phycocyanin concentration was evaluated in terms of phycocyanin concentration (Eq. (1) using distilled water. The Spirulina biomass samples were weighted.

Wet Spirulina samples of 20.09, 20.01, 20.07, 20.01 g; Spirulina waited 48 hours of 20.03, 20.04, 20.00, 20.04 g; frozen Spirulina for 48 hours of 20.04, 20.04, 20.04, 20.04 g, frozen Spirulina of 15.00 grams at for fifteen days and dried Spirulina of 2.0, 2.0, $2.03 \mathrm{~g}$ were weighed.100 mL distilled water was added to the samples. The samples were studied with three samples except for frozen Spirulina for fifteen days. The biomass was homogenized in ultra thorax at $5000 \mathrm{rpm}$ for five minutes and $15000 \mathrm{rpm}$ for one minute. The homogenized samples of $7 \mathrm{~mL}$ were placed in the centrifuge tubes and centrifuged at $5000 \mathrm{rpm}$ for five minutes. After centrifugation, the optical density of the supernatant was measured at 615 and $652 \mathrm{~nm}$.

Phycocyanin concentration (PC), according to Bennett and Bogorad (1973), was defined as

$$
\mathrm{PC}=\frac{615 \mathrm{~nm}-0.474(652 \mathrm{~nm})}{5.34}
$$

where $\mathrm{PC}$ is the phycocyanin concentration $\left(\mathrm{mg} \mathrm{mL}^{-1}\right), \mathrm{OD}_{615}$ is the optical density of the sample at $615 \mathrm{~nm}, \mathrm{OD}_{652}$ is the optical density of the sample at $652 \mathrm{~nm}$.

The purity of phycocyanin extract was monitored spectrophotometrically by the $\mathrm{A}_{615} / \mathrm{A}_{280}$ ratio (Abalde et al., 1998). This relationship is indicative of the extract purity of phycocyanin with respect most forms of contaminating proteins. Absorbance at $615 \mathrm{~nm}$ indicates the phycocyanin concentration, while that at $280 \mathrm{~nm}$ is due to the total concentration of proteins in the solution (Liu et al., 2005). The extract purity of phycocyanin (EP) was defined as

$$
\mathrm{EP}=\mathrm{OD}_{615} / \mathrm{OD}_{280}
$$

Where $\mathrm{EP}$ is the extract purity, $\mathrm{OD}_{615}$ is the optical density of the sample at $615 \mathrm{~nm}, \mathrm{OD}_{280}$ is the optical density of the sample at $280 \mathrm{~nm}$.

The yield of the extraction was defined as

$$
\text { Yield }=\frac{\mathrm{PCxV}}{\mathrm{DB}}
$$

Where PC is phycocyanin concentration $\left(\mathrm{mg} \mathrm{mL}^{-1}\right), \mathrm{V}$ is the volume of solvent $(\mathrm{mL}), \mathrm{DB}$ is dried biomass (g).

Data were subjected to analysis of variance (ANOVA) and means were separated using Fisher's Least Significant Difference (LSD) test at $\mathrm{p} \leq 0.05$. 


\section{RESULTS and DISCUSSION}

In the study carried out, PC contents were determined from the wet biomass of Spirulina, wet biomass of Spirulina kept for 48 hours at room temperature, frozen Spirulina for 48 hours, frozen Spirulina for fifteen days, and dried Spirulina.

Phycocyanin contents of $0.3119 \mathrm{mg} \mathrm{mL}^{-1}$ obtained from wet biomass of Spirulina waited for 48 hours was found higher than $0.3108,0.3043,0.2997$ and $0.24096 \mathrm{mg} \mathrm{mL}^{-1}$ obtained from wet Spirulina, frozen Spirulina for 48 hours, dried Spirulina than biomass frozen for 15 days, respectively (Table 1).

Phycocyanin yield of 17,6497, 17,1370, 17,0833, 16,7208 mg/g obtained from frozen Spirulina for fifteen days, wet biomass of Spirulina waited for 48 hours, wet biomass and frozen Spirulina for 48 hours respectively were higher than $14,8935 \mathrm{mg} / \mathrm{g}$ from dried samples (Table 1).

The purity of phycocyanin extracts of 4.60 and 2.55 were found high in the samples of Spirulina frozen for 15 days and wet Spirulina of, respectively.

Table 1. Main parameters values of phycocyanin concentration (PC), extract purity of phycocyanin (EP), and yield. Values with the different letter in each column showed a statistically significant difference between and within groups $(\mathrm{p} \leq 0.05)$

\begin{tabular}{lccc}
\hline \hline Parameters & PC $(\mathbf{m g} / \mathbf{m L})$ & EP(OD615/OD280) & Yield (mg/g) \\
\hline Frozen For 15 Days & $0.240967 \pm 0.004315^{\mathrm{b}}$ & $4.606667 \pm 1.158462^{\mathrm{a}}$ & $17.6497^{\mathrm{a}}$ \\
Frozen Spirulina for 48 hours & $0.304325 \pm 0.014516^{\mathrm{a}}$ & $0.814275 \pm 0.080285^{\mathrm{c}}$ & $16.7208^{\mathrm{b}}$ \\
Wet biomass of Spirulina (held for 48 hours) & $0.3119 \pm 0.010455^{\mathrm{a}}$ & $0.85225 \pm 0.050554^{\mathrm{c}}$ & $17.1370^{\mathrm{a}}$ \\
Dried Spirulina & $0.29975 \pm 0.004282^{\mathrm{a}}$ & $0.98205 \pm 0.02608^{\mathrm{c}}$ & $14.8935^{\mathrm{c}}$ \\
Wet Spirulina & $0.3108 \pm 0.007143^{\mathrm{a}}$ & $2.5567 \pm 0.092880^{\mathrm{b}}$ & $17.0833^{\mathrm{a}}$ \\
Prob > f & 0.0001 & 0.0131 & 0.0001 \\
LSD \% 0.05 & 0.014 & 3.671 & 0.116 \\
\hline \hline
\end{tabular}

Many studies on efficient extraction and purification of C-phycocyanin have been carried out. The phycocyanin content during the extraction with different solvents was investigated. The study was carried out by Silveira et al. (2007) about the optimization of phycocyanin extraction from Spirulina platensis and used different solvents, including, distilled water, $10 \mathrm{mM}$ sodium phosphate buffer $(\mathrm{pH}$ 7.0), $10 \mathrm{mM}$ sodium acetate buffer ( $\mathrm{pH} 5.0$ ), $\mathrm{NaCl} 0.15 \mathrm{M}$ and $\mathrm{CaCl}_{2} 10 \mathrm{~g} \mathrm{~L}^{-1}$ (Abalde et al., 1998; Bermejo et al., 2003). Silveira et al.(2007) were recorded that the higher phycocyanin contents of 3.73, 4.203 .32 , and $3.48 \mathrm{mg} \mathrm{mL}^{-1}$ with different solvents of water, phosphate buffer $\mathrm{pH} 7.0, \mathrm{NaCl} 0.15 \mathrm{M}$, and $\mathrm{CaCl}_{2} 10 \mathrm{~g} \mathrm{~L}^{-1}$ than $1.84 \mathrm{mg} \mathrm{mL}^{-1}$ of acetate buffer. In conclusion, the work described a suitable method for the extraction of phycocyanin from the S. platensis. Water was chosen as the extractant because it produced a high phycocyanin concentration. Besides, it is a low cost extractant (Silveira et al., 2007). The reason for the low PC values $\left(\mathrm{mg} \mathrm{mL}^{-1}\right)$ in our study can be explain strains of the species and the mechanical disruption of cells, which caused increased release of phycocyanin.

At the study carried out that the slurry of Spirulina dried at different temperatures (T) and relative humidity (RH). The PC values of air-dried fresh Spirulina and freeze-thawed and air-dried Spirulina were compared and no significant differences were found, so it can be confirmed that the preservation of Spirulina in a freezer did not cause serious changes in its properties. The phycocyanin contents for three protocols of T30/RH50, T50/RH20/T80/RH20 were found similar (Nakagawa et al., 2016). In this study, the PC values were found similar except the Spirulina frozen for fifteen days.

In the other study carried out with Spirulina, different phycocyanin extraction methods were compared. Spectral properties of phycocyanin were observed that extracted with water, hydrochloric acid, and homogenization in the blender. The quality of phycocyanin required would influence the selection of suitable extraction method. It was reported that fresh biomass was suitable for phycocyanin extraction (Sarada et al, 1999). In our study, we also observed that the best PC values with the wet samples of $0.31 \mathrm{mg} / \mathrm{mL}$.

The relationship is indicative of the extract purity of phycocyanin with respect to most forms of contaminating proteins. The results obtained from the studies demonstrated that the purity of the extract is significantly influenced by temperature. In the study carried out phycocyanin concentration and extract purity were shown that as a function of time. The results obtained in that work demonstrated that the purity of the extract was significantly influenced by temperature. High 
temperature resulted in reduced purity because it facilitated the extraction of other proteins (Silveira et al., 2007).

Ilter et al. (2018) was carried out a study in which different solvents of distilled water, NaPhosphate $\mathrm{pH}: 7,4$ suspension, and $1.5 \% \mathrm{CaCl}_{2}(\mathrm{w} / \mathrm{v})$ water solution were used for dry, frozen, and wet Spirulina. In that study, the highest phycocyanin content of frozen biomass was obtained using $1.5 \%$ $\mathrm{CaCl}_{2}(\mathrm{w} / \mathrm{v})$ as extraction medium with $55.33 \pm 3.23 \mathrm{mg} / \mathrm{g}$ PC. With distilled water as a solvent, $24.67 \pm 2.26 \mathrm{mg} / \mathrm{g}$ PC was obtained for frozen Spirulina biomass. In our study, a higher PC content of $17.64 \mathrm{mg} / \mathrm{g}$ was found with frozen Spirulina biomass for fifteen days with distilled water $(\mathrm{p} \leq 0.05)$.

The extract purity was favored when using low temperatures. High temperature resulted in reduced purity because it facilitated the extraction of other proteins. Since the phycocyanin concentration was only slightly affected by temperature, the increase of temperature did not improve phycocyanin extraction (Silveira et al., 2007). In that study, the room temperature was $24{ }^{\circ} \mathrm{C}$ and extract purity $\left(\mathrm{OD}_{615} / \mathrm{OD}_{280}\right)$ values were determined 4.60, 0.81, 0.85, 0.98, and 6.55 for frozen for 15 days, frozen Spirulina for 48 hours, wet biomass of Spirulina (waited for 48 hours), dried Spirulina and wet Spirulina, respectively.

C-phycocyanin extraction process for large-scale use were studied and the optimum conditions for extracting C-PC from dried, frozen biomass, milled to a small diameter, were an extraction time of 1 $\mathrm{h}$, a biomass-to-solvent ratio $0.16: 1$, and without agitation, obtaining a C-PC concentration of 13.20 $\mathrm{mg} / \mathrm{mL}$, purity of 0.603 and extraction yield of $82,48 \mathrm{mg} / \mathrm{g}$ (Moraes et al., 2010).

Oğuz et al. (2011) were carried out the experiment in the fiber-glass ponds in the greenhouse during the months of April, July, and September to determine the effect of seasonal temperature and light intensity on the blue pigment C-phycocyanin and protein content of Spirulina platensis. While C-phycocyanin content was found higher in Autumn $\left(332.7 \pm 1 \mu \mathrm{gmL}^{-1}\right)$, lower and similar in Spring and Summer $\left(327.5 \pm 2\right.$ and $323.4 \pm 1 \mu \mathrm{gmL}^{-1}$ respectively. In the study, $\mathrm{NaNO}_{3}$ was used as a solvent and read at $620 \mathrm{~nm} \mathrm{CP}$ values was calculated with the equation of $\mathrm{CP}=\mathrm{OD}_{620 \mathrm{~nm}} \times 137=\mu \mathrm{gmL}^{-}$

${ }^{1}$ (Boussiba and Richmond, 1979). The CP values were similar to the CP contents of this study, however, the water as a solvent for extraction is not harmful to health and environment, at the same time costless.

In the other study, the effect of ultrasonication process time on the extraction of phycocyanin and chlorophyll-a prior to the application of solvent extraction with methanol and aqueous sodium nitrate solution (1.5\% $\mathrm{NaNO}_{3}$ ), and the antioxidant activity (FRAP, Ferric Reducing Ability of Plasma) of extracts were determined. Ultrasonication for $1,3,5,10,15,20,30,45$, and 60 minutes were applied prior to methanol and $\mathrm{NaNO}_{3}$ solvent extraction for 120 minutes at room temperature. Chlorophyll $a$ concentration with $6.75 \mathrm{mg} / \mathrm{g}$ dry Spirulina for control sample increased to $7.70 \mathrm{mg} / \mathrm{g}$ dry Spirulina by 30 minute sonication process, and it remained constant at further sonication times. Moreover, phycocyanin concentration with $34.52 \mathrm{mg} / \mathrm{g}$ dry Spirulina for the control sample increased to 51.83 $\mathrm{mg} / \mathrm{g}$ dry Spirulina up to 45 minute sonication process and remained constant at further sonication. Antioxidant activity of chlorophyll $a$ and phycocyanin were $15.74 \mathrm{mg} / \mathrm{g}$ and $11.98 \mathrm{mg} / \mathrm{g}$, respectively for 60 minutes sonic application followed by solvent extraction. In conclusion, prior to solvent extraction, 30 minute sonication process is recommended for chlorophyll $a$ while 45 minute process for phycocyanin (Aksay and Arslan, 2018). In that study, phycocyanin extraction was performed using $1.5 \%$ sodium nitrate aqueous solutions and the phycocyanin concentration was higher than in our results because of the different solvents probably. However, as stated in this study, prior to solvent extraction sonication process will increase the yield of phycocyanin, so the sonification seems necessary in this study.

\section{CONCLUSION}

In the study, water as a solvent was used for extraction of phycocyanin. It can be said that in that study phycocyanin amount is not high as the other studies used different solvents or methods for disruption to the cells. In the trials used water as a solvent, disruption of the cells, agitation, different temperatures can be added for more effective extraction. Phycocyanin, the blue color, organic coloring, not harmful to human health, can be used in the food industry widely. However the cost of the product should be as low as possible, so the water can be preferable. 


\section{REFERENCES}

Aksay, S., \& Arslan, R. (2018) Effects of ultrasonication time on chlorophyll- $a$ and phycocyanin pigment extraction from Spirulina platensis. Akademik Glda, 16(3), 307-312.

Abalde, J., Betancourt, L., Torres, E., Cid, A., \& Barwell, C. (1998). Purification and characterization of phycocyanin from the marine cyanobacterium Synechococcus sp. 109201. Plant Science, 136(1), 109120.

Bennett, A., \& Bogorad, L. (1973). Complomentary chromatic adaptation in a filamentous blue-green alga. The Journal of Cell Biology, 58, 419-435.

Bermejo, R., Acien, F. G., Ibanez, M. J., Fernandez, J. M., Molina, E., \& Alvarez-Pez, J. M. (2003). Preparative purification of B-phycoerythrin from the microalga Porphyridium cruentum by expanded-bed adsorption chromatography. Journal of Chromatography, 790, 317-325.

Boussiba, S., \& Richmond, A. (1979). Isolation and characterization of phycocyanin from the blue-green alga Spirulina platensis. Biology Archives of Microbiology, 120, 155-159.

Eriksen, N. T. (2008). Production of phycocyanin-a pigment with applications in biology, biotechnology, foods and medicine. Applied Microbiology and Biotechnology. 80, 1-14.

Herrera, A., Boussiba, S., Napoleone, V., \& Hohlberg, A. (1989). Recovery of c-phycocyanin extract. Bioresource Technology, 100, 5312-5317.

Ilter, I., Aky1l, S., Demirel, C., Koç, M., Dalay, M. C., \& Ertekina, F.K. (2018). Optimization of phycocyanin extraction from Spirulina platensis using different techniques. Journal of Food Composition and Analysis, 70, 78-88.

Jaouen, P., Lepine, B., Rossignol, N., Royer, R., \& Quem' eneur, F. (1999). Clarification and concentration with membrane technology of a phycocyanin solution extracted from Spirulina platensis. Biotechnology Techniques, 13, 877-881.

Liu, L.N., Chen, X.L., Zhang, X.Y., Zhang, Y. Z., \& Zhou, B. C. (2005). One-step chromatography method for efficient seperation and purification of R-phycoerythrin from Polysiphonia urceolata. Journal of Biotechnology, 116, 91-100.

Moraes, C., Kalıl, S. J., \& Burke, J. F. M. (2010). C-Phycocyanin extraction process for large-scale use. Journal of Food Biochemistry, 34(1) 133-148.

Nakagawa, K., Ritcharoen, W., Sri-Uam, P., Prasert, P., \& Shuji, A. (2016). Antioxidant properties of convective-air-dried Spirulina maxima: evaluation of phycocyanin retention by a simple mathematical model of air-drying. Food and Bioproducts Processing, 100, 292-302.

Oğuz, H., Işık, O., Uslu, L., Sayın, S., \& Kargın, H. (2011). The effects of the climatic conditions of the Cukurova (Adana-Turkey) on the C-phycocyanin pigments of Spirulina platensis (Cyanophyta). Journal of Fisheries Sciences.com, 5(2), 146-152.

Reis, A., Mendes, A., Lobo-Fernandes, H., Empis, J. A., \& Novais, J. M. (1998). Production, extraction and purification of phycobiliproteins from Nostoc sp. Bioresource Technology, 66, 181-187.

Romay Ch., Gonzales, R., Ledon, N., Remirez, D., \& Rimbau, V. (2003). C-phycocyanin: a biliprotein with antioxidant, anti-inflammatory and neuroprotective effects. Current Protein and Peptide Science, 4, $207-$ 216.

Sarada, R., Pillai, M. G., \& Ravishankar; G. A. (1999). Phycocyanin from Spirulina sp: influence of processing of biomass on phycocyanin yield, analysis of efficacy of extraction methods and stability studies on phycocyanin. Process Biochemistry, 34, 795-801.

Silveira, S.T., Burkert, J. F. M., Costa, J. A. V., Burkert, S. J., \& Kalil, S. J. (2007). Optimization of phycocyanin extraction from Spirulina platensis using factorial design. Bioresource Technology, 98, $1629-1634$.

Vonshak, A. (1997). Spirulina platensis Arthrospira: Physiology, Cell-Biology and Biotechnology (A. Vonshak, ed.) 233 p. Taylor\&Francis, London. 